\title{
Formation, evolution, and drainage of short-lived glacial lakes in permafrost environments of the northern Teskey Range, Central Asia
}

\author{
Mirlan Daiyrov ${ }^{1,2}$ and Chiyuki Narama ${ }^{3}$ \\ ${ }^{1}$ Central-Asian Institute for Applied Geosciences (CAIAG), Bishkek, Kyrgyz Republic \\ ${ }^{2}$ Graduate School of Science and Technology, Niigata University, Niigata, Japan \\ ${ }^{3}$ Program of Field Research in the Environmental Sciences, Niigata University, Niigata, Japan
}

Correspondence: Mirlan Daiyrov (mirlan085@gmail.com) and Chiyuki Narama (narama@env.sc.niigata-u.ac.jp)

Received: 6 August 2020 - Discussion started: 23 October 2020

Revised: 19 May 2021 - Accepted: 31 May 2021 - Published: 29 July 2021

\begin{abstract}
In the Teskey Range of the Tien Shan (Kyrgyz Republic), five outburst flood disasters from short-lived glacial lakes in 2006, 2008, 2013, 2014, and 2019 caused severe damages in the downstream part. Short-lived glacial lakes in the Teskey Range grow rapidly and drain within a few months, due to closure and opening of an outlet ice tunnel in an ice-cored moraine complex at the glacier front. In addition to these factors, summer meltwater from the glacier can cause rapid growth. Outburst floods of this lake type are a major hazard in this region and differ from the morainedam failures common to the eastern Himalaya. To clarify how short-lived glacial lakes store and drain water over short periods, we use results from a field survey and satellite data to analyze the water level, area, volume, and discharge of Korumdu lake (2017-2019) as well as satellite data to monitor the appearance of 160 other short-lived lakes (20132018). Except in 2016, Korumdu lake appeared and drained within about 1 month during all the summers. Water level data recorded by a data logger and time-lapse camera images show that the lake appeared and expanded suddenly from July to August in 2017-2019. The timing of lake appearance indicates that the lake formed when an outlet ice tunnel (subsurface channel) drainage was blocked by depositions of an ice-debris mixture due to ice melting and not by freezing of stored water. For 2017, we used uncrewed aerial vehicle (UAV)-derived digital surface models (DSMs) and water levels, finding that the lake's volume reached $234000 \mathrm{~m}^{3}$ within $29 \mathrm{~d}$, and then the water discharged for $17 \mathrm{~d}$ at a maximum rate of $0.66 \mathrm{~m}^{3} / \mathrm{s}$. This discharge rate is more than 20
\end{abstract}

times smaller than those found earlier (2006-2014) for four short-lived lakes of tunnel type in this region. We argue that this large variation in discharge rates is due to variation in the dimensions of the outlet ice tunnels. For the 160 other short-lived glacial lakes, we found that 117 formed during the ice-melt period from July to September. This timing and our findings for Korumdu lake show that these 117 lakes likely formed primarily because deposition of an ice-debris mixture blocked the outlet tunnel, though increased glacial melt would also have contributed. In the Teskey Range, the appearance of short-lived glacial lakes on the moraine complexes at glacier fronts is inevitable in summer when the melting rate is high. Similar behavior of short-lived lakes may occur in other mountain regions of Central Asia, such as the Tien Shan and Pamir Mountains, wherever ice-cored moraine complexes exist within mountain permafrost zone. Moreover, increasing temperatures may increase both tunnel size and lake-basin size (lake volume), leading to increased hazard potential from such lakes in the future.

\section{Introduction}

Compared to the large proglacial lakes in the eastern Himalayas (Ageta et al., 2000; Komori et al., 2004; Bajracharya et al., 2007; Nagai et al., 2017), glaciers in the northern Tien Shan (Central Asia) tend to have small glacial lakes near their termini (Janský et al., 2008; Narama et al., 2010a, 2015). Drainage events from these lakes often produce hazardous 
debris flows and floods. For example, debris flows in 2006, 2008, 2013, 2014, and 2019 in the Teskey Range of the northern Tien Shan caused severe damage (including casualties) and destroyed bridges, roads, houses, and crops (Narama et al., 2010a, 2018; Daiyrov et al., 2020).

Some of these small lakes are called short-lived as they grow rapidly and drain within a few months (Narama et al., 2010a, 2018; Daiyrov et al., 2018). Such short-lived lakes appear in depressions of ice-cored moraine complexes at glacier fronts. The lakes drain through an outlet ice tunnel (subsurface channel) within the moraine complex (Popov, 1987; Narama et al., 2010a, 2018). Some authors call them nonstationary lakes (Erokhin et al., 2017), though this term also includes lakes with a long lifetime. Most short-lived glacial lakes fill periodically and within 1 year, though some may develop for 2-3 years before draining. The latter type is also dangerous; for example, in the Tajik Pamirs, drainage from a short-lived glacial lake that formed within 2 years resulted in 25 casualties (Mergili et al., 2012). In northern Tien Shan, short-lived glacial lakes can be a severe hazard for local residents because they appear suddenly yet can cause large debris flows. Outburst mechanism and damage potential of short-lived glacial lakes in the northern Tien Shan differ from those that are caused by moraine-dam failure in the Himalaya and Andes (Costa and Schuster, 1988; Richardson and Reynolds, 2000; Shreshta, 2010; Emmer and Cochachin, 2013; Neupane et al., 2019). A mass movement such as an ice avalanche or landslide is often the main cause of dam failures of the glacial lakes in the Himalayas and Andes (Emmer and Cochachin, 2013; Neupane et al., 2019).

Short-lived glacial lakes that are dammed by partially frozen moraine material (ice-cored moraine complex) drain through a subsurface outlet ice tunnel. These lakes can expand rapidly when the outlet ice tunnel is blocked due to either freezing of stored water or depositions of ice and debris (Narama et al., 2010a, 2018). Drainage then occurs when the outlet ice tunnel opens during summer. Some of these shortlived glacial lakes reappear every year (Daiyrov et al., 2018), which is behavior they share with supraglacial lakes. Several studies reported that formation and drainage of supraglacial lakes are related to connectivity of englacial conduits on a debris-covered glacier (Benn et al., 2000, 2017; Miles et al., 2016; Watson et al., 2016; Narama et al., 2017). However, the variations of short-lived glacial lakes in northern Tien Shan arise from their ice tunnel opening and closing as well as the increase in glacial melt during summer (Daiyrov et al., 2020).

Short-lived glacial lakes in the northern Tien Shan appear at depressions that can be created when a glacier retreats, when an ice-cored moraine complex subsides (Narama et al., 2010a, 2018; Daiyrov et al., 2018). Narama et al. (2018) showed that such short-lived glacial lakes typically form where the following three conditions exist: (1) an ice-cored moraine complex (debris landform containing ice), (2) a depression with a water supply to an ice-cored moraine complex or glacier terminus, and (3) the absence of a visible sur- face outflow channel from the depression. The last condition indicates that the moraine complex has an outlet ice tunnel to drain lake water.

The number and area of glacial lakes in the Tien Shan has recently increased, a trend that is linked to climatic warming and glacier shrinkage (Bolch et al., 2011; Wang et al., 2013; Kapitsa et al., 2017). In addition, Daiyrov et al. (2018) showed that the large variability in the number and distribution of glacial lake types in the Issyk-Kul basin is not only related to the local climate conditions, but also to the three conditions in the glacier forefield described above.

Many short-lived glacial lakes have been observed in the northern Tien Shan in recent years (Daiyrov et al., 2018). They can change in area and volume over a short period of time, making their drainage features and discharge rates unpredictable (Erokhin et al., 2017), but not all short-lived glacial lakes cause large-scale floods. A short-lived lake's fate depends on whether the dam contains ice (Mergili et al., 2013) and, if so, how the outlet ice tunnel closes and opens. However, the mechanisms of lake formation and drainage remain unclear. Hazards from an abruptly changing glaciallake discharge can intensify dramatically and unexpectedly within weeks or even days (Huggel, 2004).

In this study, we investigate formation and drainage mechanisms of Korumdu lake in the Teskey Range, Tien Shan (Kyrgyz Republic), and the reason for different discharge (rates) from short-lived lakes based on field survey and satellite data analysis. To clarify how the other short-lived lakes in the Teskey Range form and drain water, we investigate their timing of appearance during summer months between 2013 and 2018 using Landsat 7/8, Sentinel-2, and PlanetScope satellite images. Finally, we discuss the causes of outlet ice tunnel closure for Korumdu lake and other lakes of the same type in the study area. We also examine the relationship between outlet tunnel size and lake drainage rate.

\section{Study area}

The study area is situated in the northern part of the Teskey Range, south of Lake Issyk-Kul (Fig. 1). The glacier distribution (3700-4200 $\mathrm{m}$ a.s.l.) in the western part of the range is lower than the distribution (3800-4500 $\mathrm{m}$ a.s.l.) in the eastern part due to the annual precipitation being higher in the eastern part than in the western part. For example, during 19982007 , the average annual precipitation at the Kara-Kujur station (2800 m a.s.1.) of the western part was $255 \mathrm{~mm}$, whereas at the Tien Shan station ( $3614 \mathrm{~m}$ a.s.l.) of the central part it was $378 \mathrm{~mm}$, and at the Chong-Ashu station (2788 m a.s.l.) of the eastern part it was $550 \mathrm{~mm}$ (Podrezov and Ryskal, 2019; Fig. 1). Mean annual air temperature was $0.1^{\circ} \mathrm{C}$ (19611988) for Kara-Kujur, $-6.28^{\circ} \mathrm{C}(1995-2011$; Kuzmichenok, 2013) for Tien Shan and $0.27^{\circ} \mathrm{C}$ (1995-2005) for ChongAshu. The western part of the range showed less glacier 
shrinkage than that in the eastern part (Aizen et al., 2006; Narama et al., 2006; Kutuzov and Shahgedanova, 2009).

In this area, the five large drainage events of Kashkasuu (2006), western Zyndan (2008), Jeruy (2013), Karateke (2014), and Toguz-Bulak (2019) recently occurred from short-lived glacial lakes that formed on ice-cored moraine complexes (debris landforms including ice) (Narama et al., 2010a, 2018; Daiyrov et al., 2020). The ice-cored moraine complexes here lie at 3200-4000 ma.s.1. (Daiyrov et al., 2018) at the glacier fronts that developed during the Little Ice Age (Dikih, 1982; Shatravin, 2007; Narama et al., 2010b) due to ice and debris stagnating during glacier shrinkage after several glacier advances (Iwata et al., 2005).

We ran a field survey at Korumdu lake at $3806 \mathrm{~m}$ a.s.l. (Figs. 1, 2). The Korumdu catchment is source to the largest tributary in the Tong River Basin, and according to a Sentinel-2 satellite image of 2019, the Korumdu glacier occupies an area of $2.35 \mathrm{~km}^{2}$. At the front of the Korumdu glacier lies the Korumdu glacial lake (Fig. 2). The dam of this lake is an ice-cored moraine complex. The lake developed in a depression that formed during the retreat of the glacier and retains direct contact with the glacier. We selected this lake for field surveys because (i) the lake is a short-lived type that appears every year, (ii) it is easy to access, and (iii) it is located in the Tong region where four large outburst floods occurred in the past. According to data in Narama et al. (2018), outburst drainage from Korumdu lake is the flood-wave type in the downstream region because the water stream flows on a gentle slope, in which the flow hardly acquires any debris by erosion. In addition, we investigated the timing of appearance for 160 short-lived lakes in the northern Teskey Range during 2013-2018 (Fig. 1) using Landsat 7/8, Sentinel-2, and PlanetScope satellite images (Supplement Table 1).

\section{Methods}

\subsection{Field observations at Korumdu lake}

The field survey at Korumdu lake (Figs. 1, 2) was run during the summers of 2015-2019. We installed water level and water temperature data loggers (Hobo U20) at lake bottom and ground surface on the moraine to collect measurements once per hour since 21 August 2015. Water level logger measurements (water pressure data) at lake bottom were converted to the water level (meter) using atmospheric pressure data at the adjacent ground surface on the moraine. A time-lapse camera (Brinto) was installed as well, which took one oblique image of the area per day.

In addition, we obtained aerial images of the lake basin acquired by Phantom-4 (DJI) and JABO H601G (Medix) uncrewed aerial vehicles (UAVs) with a mounted camera (Ricoh GR) on 21 August 2015, 12 August 2016, 6 August 2017, 20 July 2018, and 4 August 2019. High-resolution orthoimages and digital surface models (DSMs; resolution of
$0.2 \mathrm{~m}$ ) were made using the Pix4D mapper (Pix4D SA) of structure from motion (SfM) software and ground control points (GCPs). We collected the GCPs around the lake using a Trimble GeoExplore 6000 Global Navigation Satellite System (GNSS). The absolute positions of GCPs were corrected during post-processing using data from the Kyrgyz GNSS reference station and had an accuracy of $30-40 \mathrm{~cm}$. Surface elevation changes of the moraine complex surrounding the lake were computed in ArcGIS 10.5 by comparing UAV-derived DSMs from 2015 and 2016.

The daily volume and discharge of the lake during the summers of 2017-2019 were calculated using the daily water level data and the 2017-2019 UAV-derived DSMs combined with the 2016 UAV-derived DSM (without water) in ArcGIS 10.5. For the water volume of the lake's bottom layer, we used the 2016 DSM because the 2017-2019 DSMs had water at the lake bottom. In addition, we investigated whether satellite remote sensing data could replace in situ water level logger data to calculate lake water levels using the combined DSMs. We found that the water level logger measurements agreed with the derived water levels based on UAV-derived DSMs combined with satellite imagery. For example, we confirmed the position of the water level by comparing a UAV orthorectify image or satellite data with $1 \mathrm{~m}$ contour lines from the combined UAV-derived DSMs. Finally, we obtained the water level and lake area from satellite data. Using this method, we reconstructed the water level data between 4 and 31 August 2019 based on 9 satellite images from PlanetScope and Sentinel-2 because we do not have water level data after our last field survey on 4 August 2019. We also investigated the changes in lake area during 2017-2019 using PlanetScope images.

Finally, we examined the meteorological and thermal conditions using air and ground temperature data loggers (TR-52i, T\&D; accuracy $\pm 0.3{ }^{\circ} \mathrm{C}$ ) to $\log$ data at $1 \mathrm{~h}$ intervals around the lake (Fig. 2). Mean annual air temperature (MAAT) between 2015 and 2017 and mean annual ground surface temperature (MAGST) during 2015-2019 were calculated.

\subsection{Timing of appearance of short-lived lakes using satellite data}

Short-lived glacial lakes in the northern Teskey Range were identified in ArcGIS 10.5 using satellite images (Landsat 7 Enhanced Thematic Mapper Plus (ETM+, SLC-off), Landsat 8 Operational Land Imager (OLI), Sentinel-2, and PlanetScope) acquired during 2013-2018 (Supplement Table 1). We used the definition by Daiyrov et al. (2018) for shortlived lakes, which is based on seasonal changes in lake area over the summer months of each year. Specifically, a shortlived lake is a temporary lake, lasting just 1 or 2 years, that suddenly appears or increases substantially in area and then disappears or shrinks within the same year. We counted the number of lakes that appeared from June to September each 


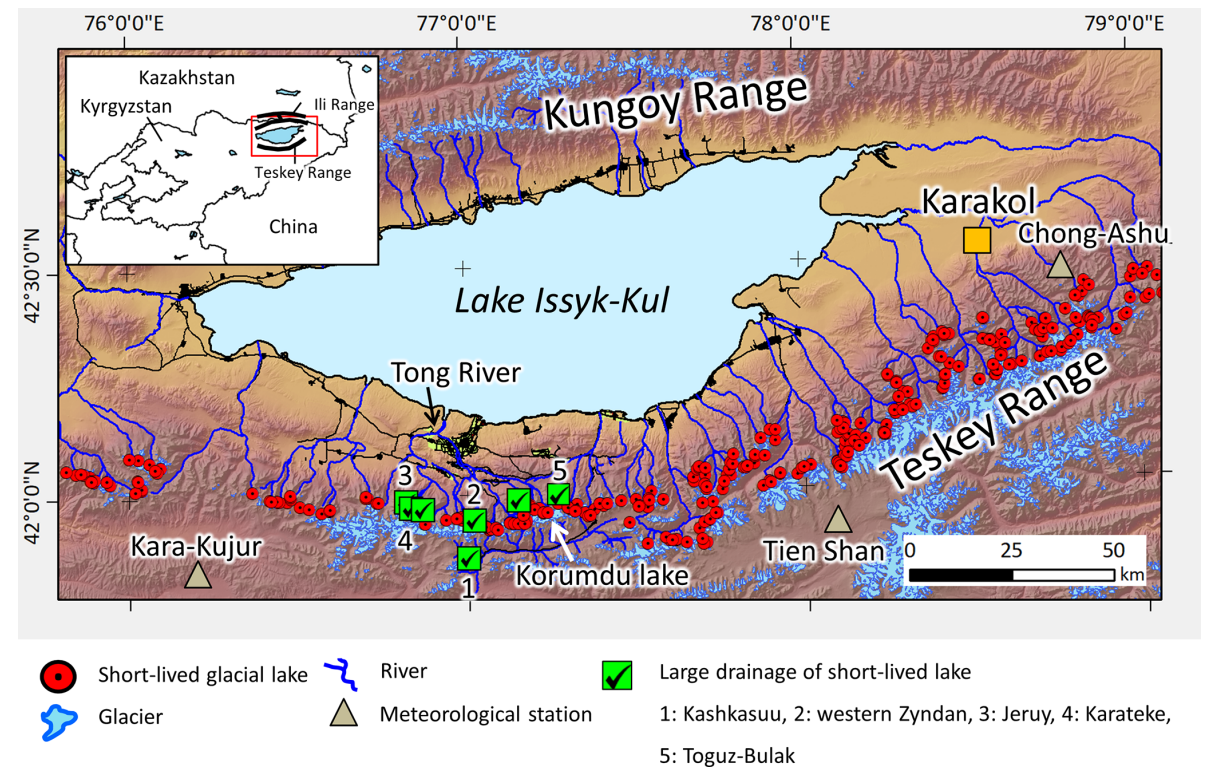

Figure 1. Study area in the northern part of the Teskey Range located on the south of Lake Issyk-Kul, Kyrgyz Republic. Red circles indicate locations of short-lived glacial lakes that appeared in 2013-2018. Green squares with checks show short-lived glacial lakes that have caused large drainage events since the 1970s. The shaded relief map was created using a Shuttle Radar Topography Mission (SRTM) digital elevation model (DEM).

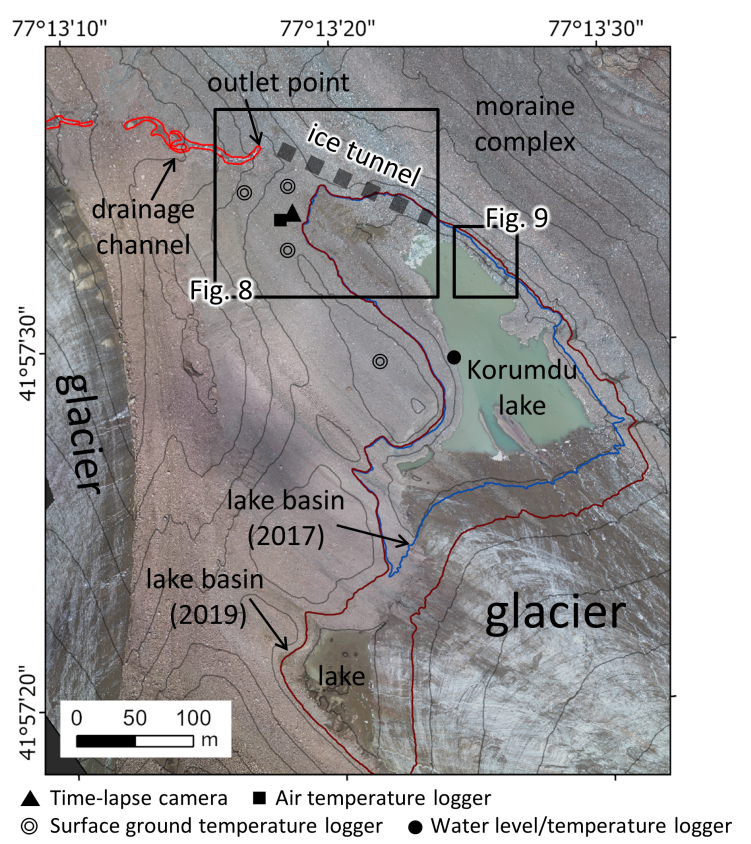

Figure 2. Overview of the Korumdu glacier front. The location of the glacier is shown in Fig. 1. Orthoimages were acquired by our UAV imagery in 2019 . Contour spacing is $10 \mathrm{~m}$.

year. In addition, the number of lakes was tracked in each given year to examine how it changed from one year to the next. Polygon shapefiles of lakes were digitized manually from the images using ArcGIS 10.5. We also investigated the area changes of short-lived glacial lakes during summer months in a given year.

\section{Results}

\subsection{Areal variability of Korumdu lake}

ALOS AVNIR-2 data taken on 17 September 2007 indicated that most of the lake basin had been covered by Korumdu glacier. Thus, the lake basin developed in a depression that formed during the retreat of the glacier in recent years. The UAV orthoimage of the basin in 2019 indicated a length of $360 \mathrm{~m}$, a width at mid-length of $110 \mathrm{~m}$, and a total area of $0.062 \mathrm{~km}^{2}$. The lake basin volume increased from 264000 to $330000 \mathrm{~m}^{3}$ from 2017 to 2019 (Fig. 2) due to retreat of the glacier terminus. In the field, we observed ice-exposed ridge and debris sliding on the basin's slope, indicating that the ice was melting around the shore, thus increasing the basin's width.

The lake had no discernable surface drainage channel, but we found an outlet point where meltwater from the lake emerges from a subsurface ice tunnel within the ice-cored moraine complex that connects to the lake (Fig. 2). The length of the outlet ice tunnel is $60 \mathrm{~m}$ from the entrance of the lake basin. During the fieldwork, we observed meltwater draining at the outlet point on 30 July 2015, 6 August 2017, and 4 August 2019 but not on 12 August 2016 and 20 July 2018. 
Concerning lake size changes, in 2015, the lake appeared sometime before 30 July and then shrank significantly by 21 August (Fig. 3). In 2016, according to the water level data and on-site time-lapse camera images, the lake area did not form. For 2017-2019, more images of the area could be acquired and thus a more detailed evolution of changes in lake size is shown with a sequence of PlanetScope satellite images in Fig. 4. The images show that the lake appears suddenly at the end of July to the beginning of August and then shrinks and vanishes by the end of August (Fig. 4). Although the timing of lake expansion differs slightly over the years 2017-2019, the lake always appears in summer. The timelapse on-site images show the same behavior from a different view (Fig. 5). These images also indicate that the lake began to expand from mid-July and reached its maximum size at some time between late July and early August. Thus, these data demonstrate that the lake is a short-lived glacial lake.

\subsection{Changes in water level, area, volume, and discharge of Korumdu lake}

Changes in water level, area, volume, and discharge of Korumdu lake were studied in detail during the three summers of 2017-2019. For 2017, Fig. 6a shows the water level increasing from 6 July, reaching a maximum on 3 August, and then the lake is empty on 19 August. Within $29 \mathrm{~d}$, the water level increases $13 \mathrm{~m}$, the area reaches $0.36 \mathrm{~km}^{2}$ (Fig. 6b), and the volume reaches $234000 \mathrm{~m}^{3}$ (Fig. 6c). The resulting rate of lake volume increase is $8070 \mathrm{~m}^{3}$ per day. During the emptying of the lake, $234000 \mathrm{~m}^{3}$ of water drains in $17 \mathrm{~d}$, with half of the volume draining from 3 to 7 August 2017 (Fig. 6c), resulting in a maximum net outflow discharge of $0.66 \mathrm{~m}^{3} / \mathrm{s}$ (Fig. 6d). Although the water level increases intermittently before 3 August, the net outflow is nearly continuous. The lake water temperature averages about $1^{\circ} \mathrm{C}$ (Fig. 6a). The water temperature fluctuates more when the lake is shallower because the heating of shallower water by solar irradiance is stronger than cooling from inflowing ice meltwater.

In 2018, the water level peaks three times, though it reaches only about half that of 2017 (Fig. 6a). The first peak, on 25 July, occurs with a lake depth of $3.5 \mathrm{~m}$ and a volume of $21000 \mathrm{~m}^{3}$ (Fig. 6a, c). The second, and maximum peak, occurs on 11 August with a lake depth of $6 \mathrm{~m}$ and a volume of $53000 \mathrm{~m}^{3}$. The third peak occurs on 17 August with a lake depth of $5 \mathrm{~m}$ and a volume of $39000 \mathrm{~m}^{3}$. The maximum net discharge occurs after the second peak, reaching $0.32 \mathrm{~m}^{3} / \mathrm{s}$ (Fig. 6d). Similar to 2017, the net inflow rate also clearly varies over time in 2018.

In 2019, the lake water level rises and falls before 22 July, when it rises sharply (Fig. 6a). Then, the water level shows a maximum around 30-31 July, reaching a lake depth of $5 \mathrm{~m}$ and a volume of $53000 \mathrm{~m}^{3}$. The 2019 maximum level occurs on 11 August, with a lake depth of $6.5 \mathrm{~m}$ and a corresponding volume of $74000 \mathrm{~m}^{3}$ (Fig. 6a, c). The maximum dis- charge occurs right after the second peak, reaching $0.48 \mathrm{~m}^{3} / \mathrm{s}$ (Fig. 6d).

Over all 3 years, the highest water level is in 2017 (Fig. 6a). In general, each year differs in the timing of lakelevel increase, number of peaks, and maximum water volume. All 3 years have relatively small net discharge rates (maxima of $0.66,0.32$, and $0.48 \mathrm{~m}^{3} / \mathrm{s}$ in 2017,2018 , and 2019), which is consistent with the absence of reported flooding.

During each of these years, the lake level rose and fell several times, indicating repeated storage-drainage cycles. In the field, we observed sudden small increases in water level in 2016 and 2017, with the lake level increasing tens of centimeters within $3 \mathrm{~h}$ (Fig. 7). These results indicate that water level fluctuations occurred frequently due to closing and opening of the outlet ice tunnel.

During the fieldwork, we observed lake water draining out an outlet point in 2015, 2017, and 2019 but not in 2016 and 2018. In years in which drainage occurred, the lake elevation exceeded that of the outlet ice tunnel entrance. For example, the water levels were at $3810 \mathrm{~m}$ a.s.1. on 21 August 2015, $3816 \mathrm{~m}$ a.s.l. on 6 August 2017, and $3810 \mathrm{~m}$ a.s.l. on $4 \mathrm{Au}-$ gust 2019, all above that of the outlet ice tunnel entrance at approximately $3807.5 \mathrm{~m}$ a.s.1. In contrast, in 2016 and 2018, lake water levels were lower than $3807.5 \mathrm{~m}$ a.s.l., the outlet tunnel elevation (Fig. 8a, c). Therefore, the field-survey results indicate that the key factor determining where drainage occurs is the relative elevations of the lake surface and outlet ice tunnel entrance.

\subsection{Surface changes on ice-cored moraine complex around Korumdu lake}

Between 2015 and 2016, debris sliding and horizontal backwasting around the lake exposed an ice ridge of up to $7 \mathrm{~m}$ height (Fig. 9). The backwasting indicates that melting of debris-covered ice occurred, which is supported by comparing the UAV-derived DSMs from both years (Fig. 9c). For instance, along the cross-sectional profile a-a' in Fig. 9b, the surface elevation decreased by about $5 \mathrm{~m}$ (Fig. 9c). These results are consistent with closure in the outlet ice tunnel during ice-melt period due to debris sliding and ice-debris deposition. During our fieldwork in 2016, we observed water flow at the entrance of an ice tunnel. After 2 or $3 \mathrm{~h}$, the lake level increased (Fig. 7), consistent with the cause being closure of the ice tunnel.

In the northern part of the Teskey Range, the discontinuous mountain permafrost zone lies above 3100-3200 m a.s.1. (Daiyrov et al., 2018). Around Korumdu lake (3806 m a.s.1.), the mean annual air temperature (MAAT) during 2015-2017 was $-4.8^{\circ} \mathrm{C}$, and the mean annual ground surface temperature (MAGST) during 2015-2019 was $-2.9^{\circ} \mathrm{C}$. Thus, the buried ice of the ice-cored moraine complex at Korumdu lake is maintained under a permafrost environment. Melting of buried ice causes surface changes including expansion of the 

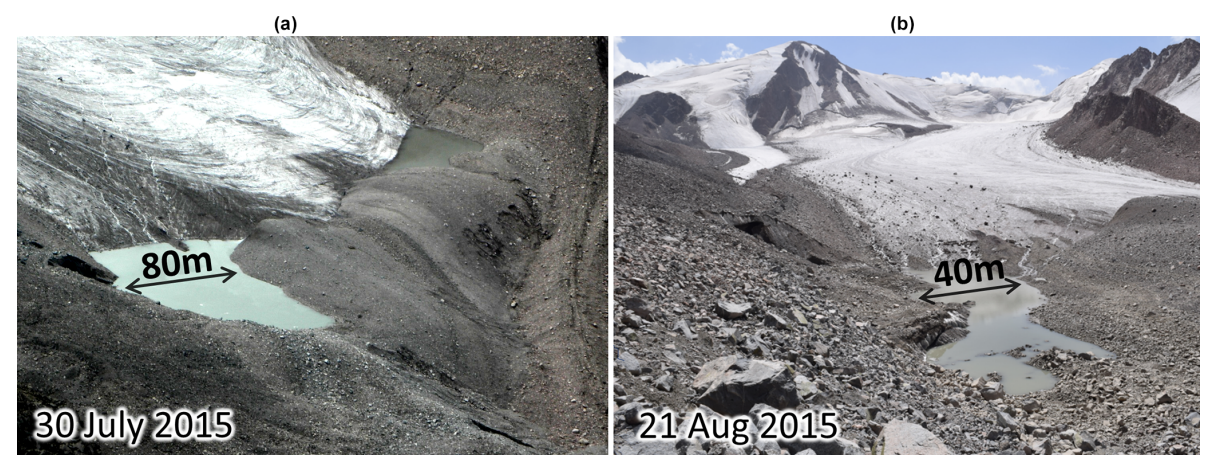

Figure 3. Korumdu glacial lake on 30 July 2015 (from a helicopter) and 21 August 2015 (from field observation). Lake width at mid-length is about $80 \mathrm{~m}$ (a) and $40 \mathrm{~m}$ (b).

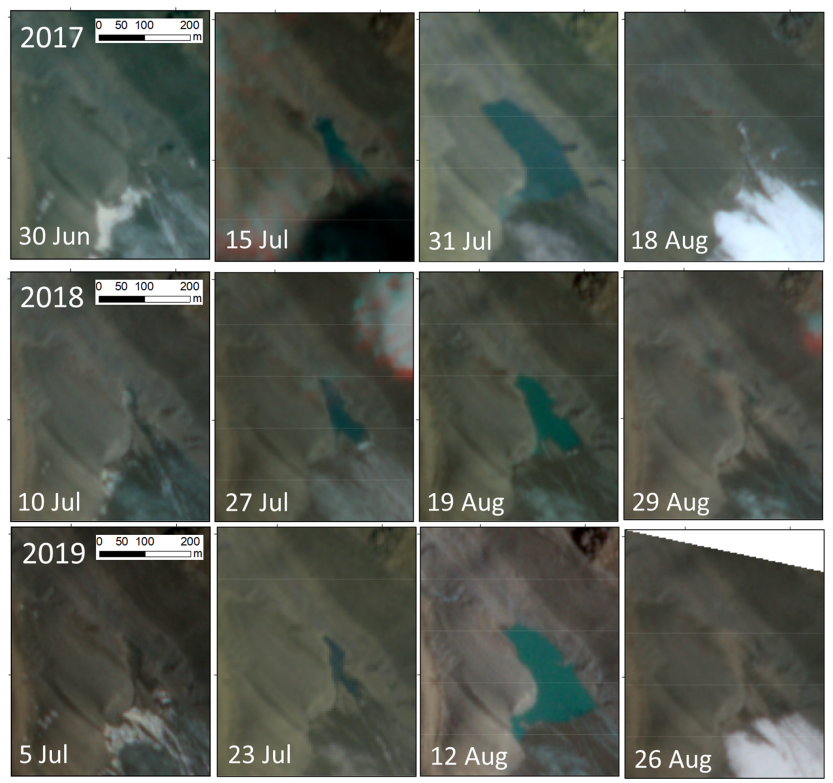

Figure 4. Time sequence of satellite images (PlanetScope) of Korumdu lake in 2017, 2018, and 2019.

lake basin and expansion and deposition (closure) in the outlet ice tunnel.

\subsection{Comparison to other short-lived glacial lakes of the Teskey Range}

To determine when other short-lived glacial lakes in the northern Teskey Range formed, we used satellite images of 2013-2018 (see Supplement Table 1). Based on the satellite imagery, a total of 160 short-lived glacial lakes could be identified. A classification of these lakes by month of appearance is shown in Fig. 10. Most lakes appeared in June (43 lakes) during the snow-melt period and in July (90 lakes) during the ice-melt period. The total numbers and the proportions of the numbers for these two periods varied during the 6 years. The number of lakes vary greatly by year and by appearance date,

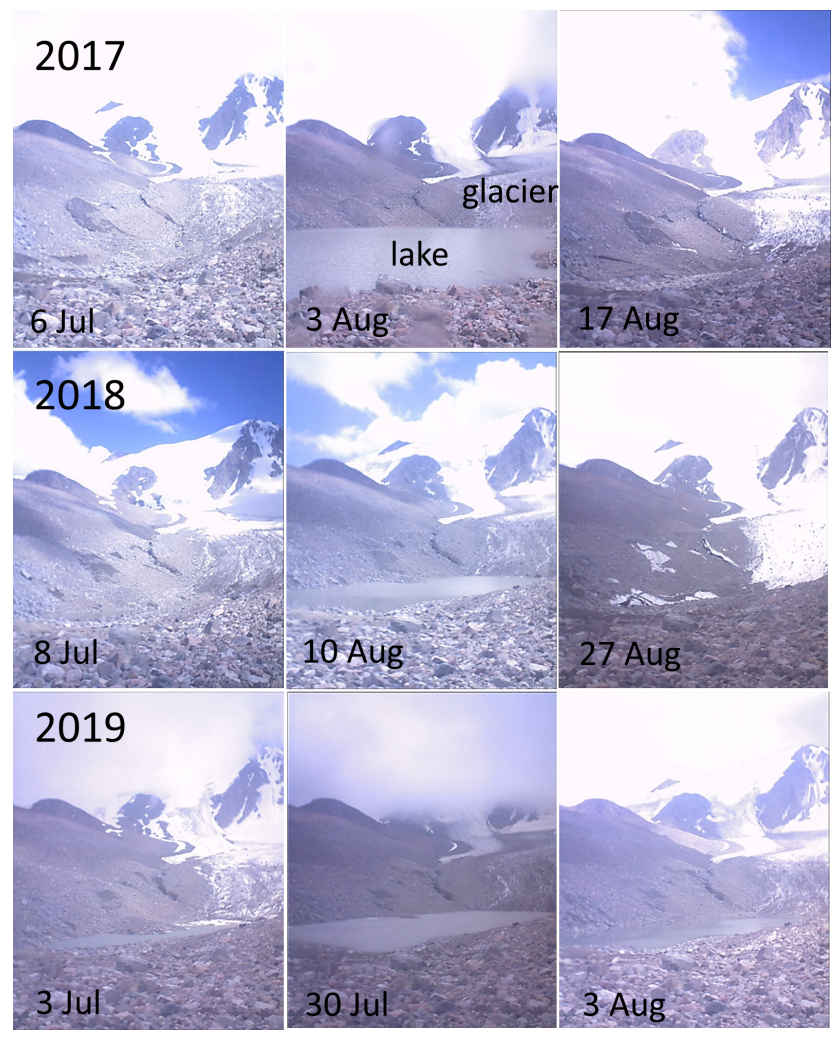

Figure 5. Korumdu lake during 2017-2019 from on-site on timelapse camera images acquired in the field.

indicating that the formation of these short-lived glacial lakes can not be explained solely by an increase in meltwater during summer. Such variability has been argued to be related to geomorphological conditions such as drainage through ice tunnel inside of ice-cored moraine complex (Daiyrov et al., 2018).

Concerning reappearances, 81 lakes appeared only once during 6 years. Of the remaining, 19 lakes appeared twice, 7 lakes appeared three times, 2 lakes appeared four times, and 2 lakes appeared all 6 years. These results are consistent with 

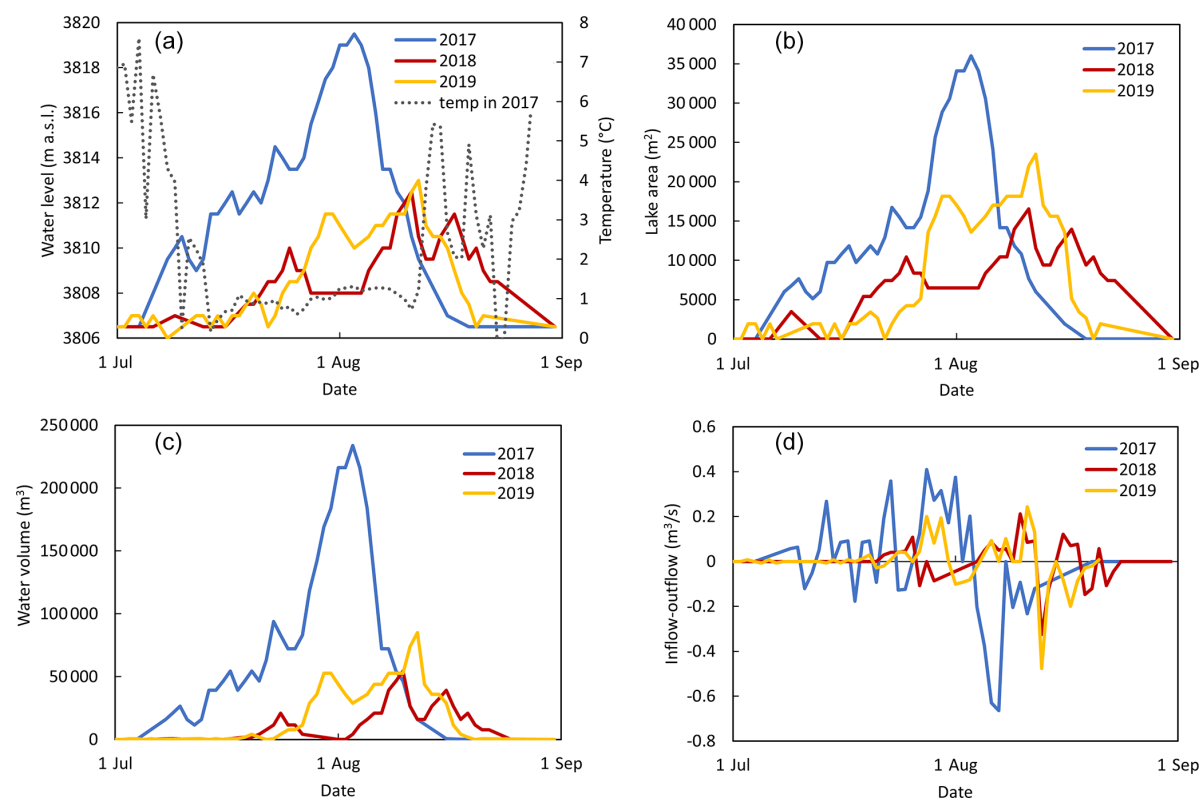

Figure 6. (a) Water levels and water temperature, (b) lake area, (c) lake volume, and (d) inflow-outflow rate of Korumdu lake during summer months of 2017-2019. Data based on water level logger data, UAV-derived DSMs, time-lapse camera images, and PlanetScope and Sentinel-2 satellite images.

tunnel closure being the main cause of formation. Short-lived glacial lakes that reappear during many years likely have an environment that either favors tunnel closure and hence lake formation or an increase in meltwater from glacier during summer (Daiyrov et al., 2020).

\section{Discussion}

\subsection{Causes of outlet ice tunnel closure in the northern Teskey Range}

We first consider four previously studied short-lived lakes of tunnel type in this area. The Kashkasuu (2006), western Zyndan (2008), Jeruy (2013), and Karateke (2014) lakes appeared in May-June and expanded in area until June-July, and then all had relatively large drainage events leading to serious damages (Narama et al., 2010a, 2018). This timing of lake appearance suggests an ice tunnel closure that is caused by the freezing of stored water during winter or deposition of ice-debris mixture as sketched in Fig. 11a (Popov, 1987; Narama et al., 2010a, 2018). We call this the depositionfreezing type of ice tunnel closure.

In contrast, Korumdu lake appeared during July-August (except in 2016) and produced relatively little drainage during emptying. This different appearance time might reflect a different formation process. As we observed subsidence and downwasting changing the lake basin (Fig. 9), the blockages of the outlet ice tunnel at its entrance or interior were likely caused by deposition of ice-debris mixture from thermal erosion. This type of blockage (deposition-collapse type) is sketched in Fig. 11b. The water level fluctuations support this mechanism. The fluctuations of lake water level and discharge spikes reveal changes in the ice tunnel morphology (Fig. 6d). A sudden blockage of an outlet ice tunnel can cause a rapid increase in water level within a few weeks. Also, the water level increase was sporadic, indicating that the outlet ice tunnel was not completely closed, the blockage was temporary, and the size of the ice tunnel is small. As a result, lake drainages can occur any time in summer, depending on how the outlet ice tunnel responds to changes in water pressure or deposition of ice-debris mixture through melting processes.

In the northern Teskey Range, the Toguz-Bulak glacial lake appeared in June and disappeared in September every year from 2010 through 2019 due to the inflow of glacier meltwater (Daiyrov et al., 2020). This lake has a surface drainage channel from the lake, but its incoming glacial runoff controls its behavior, such as its area. Thus, as for short-lived glacial lakes with surface drainage channels like Toguz-Bulak, the evolution of the glacier mass balance during summer (amount of snow and ice melt flowing into the lake) also plays an important role for the formation and evolution of short-lived glacial lakes having a subsurface outlet ice tunnel.

In 2017, there were two trends in water volume of Korumdu lake (Fig. 6c). The first period (5-25 July) involved sporadic fluctuations superimposed on an increase in water volume, indicating incomplete closure of the ice tunnel. Then, in the second period of 26 July to 3 August, the volume continuously and rapidly increases, indicating complete closure of the ice tunnel. Hence, we argue that the main factor of 

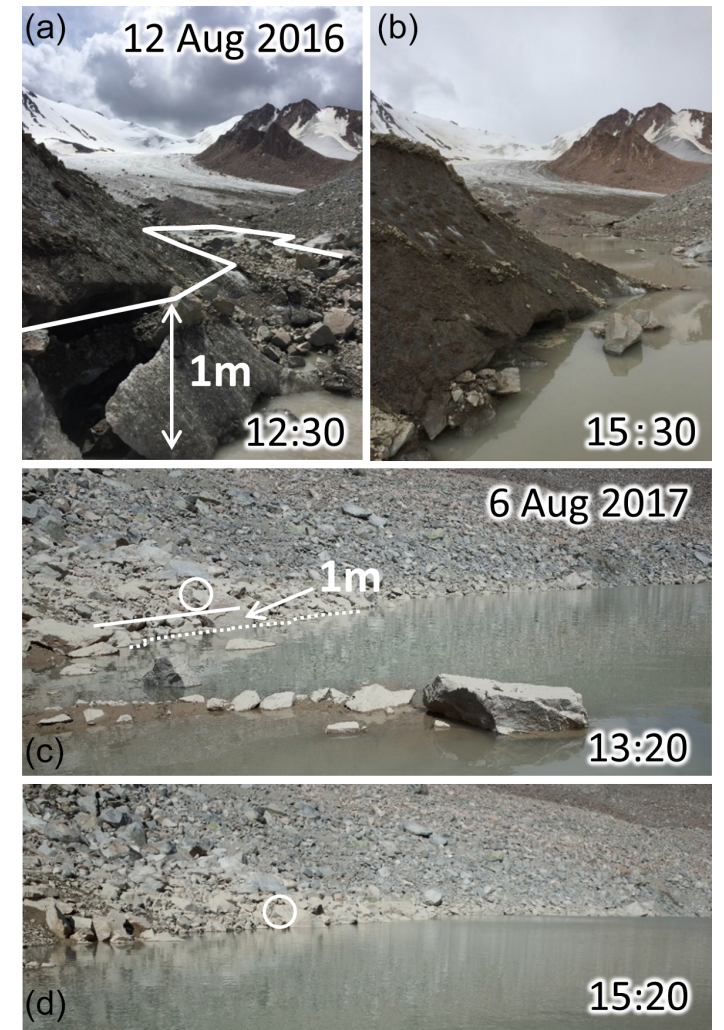

Figure 7. Two examples of a sudden increase in water level of Korumdu lake. (a) On 12 August 2016. (b) Same as panel (a) except $3 \mathrm{~h}$ later. (c) On 6 August 2017. (d) Same as panel (c) except $2 \mathrm{~h}$ later. Images were taken in the field.
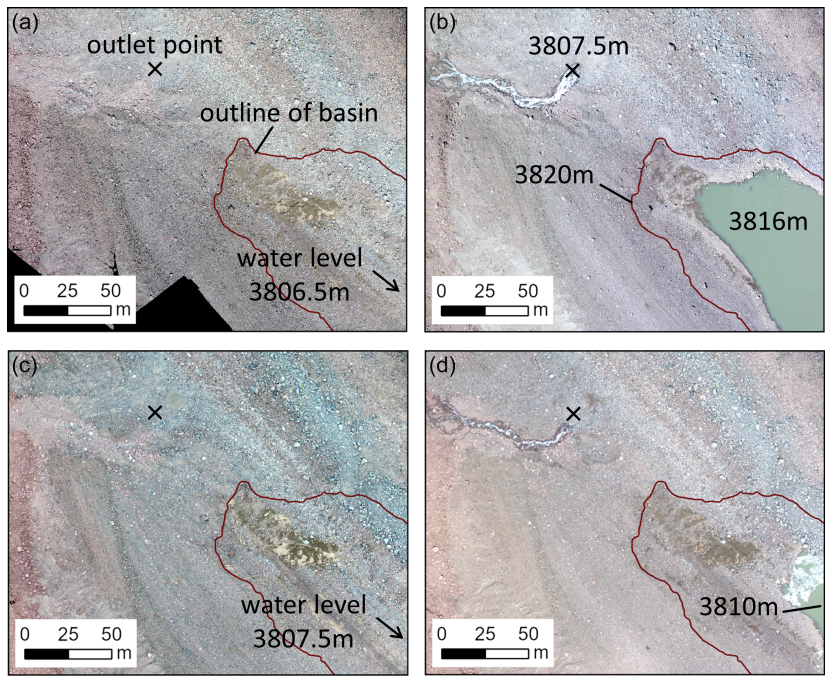

Figure 8. One-day drainage events from Korumdu lake. (a) On 12 August 2016. (b) On 6 August 2017. (c) On 20 July 2018. (d) On 4 August 2019. Images from UAV surveys.

these rapid lake-area changes is tunnel closure. The lake area reached its maximum in 2017. This indicates that the tunnel
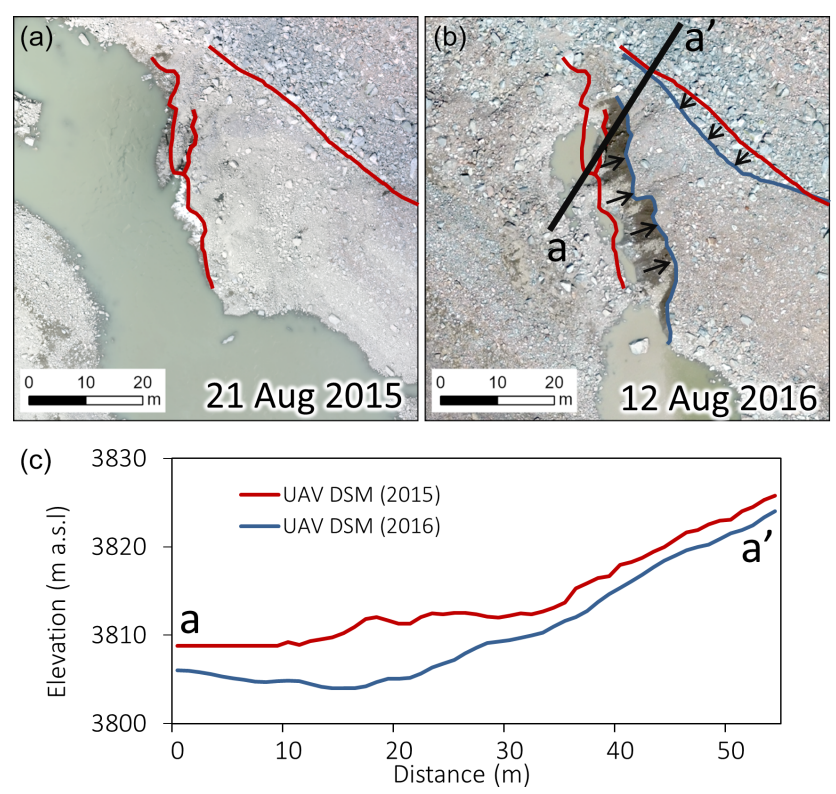

Figure 9. Surface features and elevation profiles of the debriscovered stagnant ice at the entrance of the outlet ice tunnel based on UAV orthoimages. (a) On 21 August 2015. Left red line shows the position of the exposed ice edge of the debris surface before the ice cliff underwent backwasting and melting. Right red line shows the deposition line of boulders on the slope. (b) Same as panel (a) except on 12 August 2016. The blue lines show the new positions of the respective surface features after 1 year. (c) Elevation profile of the surface along line $\mathrm{a}-\mathrm{a}$ ' in panel (b).

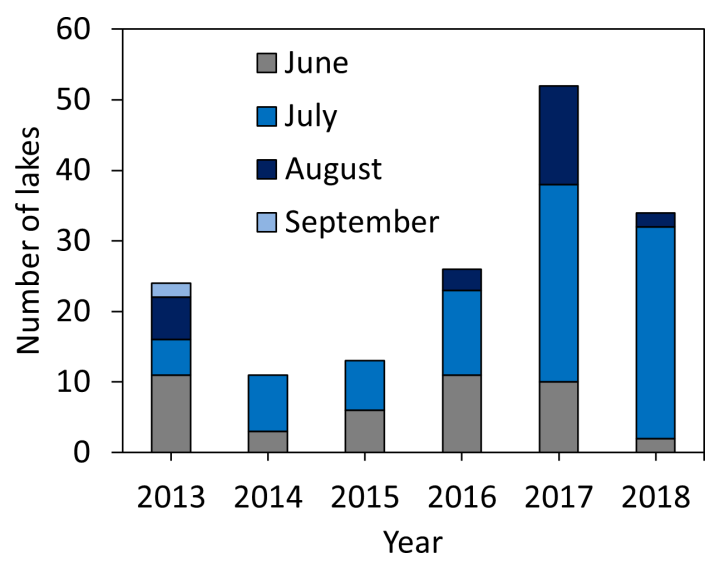

Figure 10. Total number of short-lived lakes in the months of JuneSeptember during 2013-2018 in the northern part of the Teskey Range derived by Landsat 7/8, Sentinel-2, and PlanetScope satellite images.

closure was longer in 2017 than in 2018 or 2019. Longer periods of tunnel closure are associated with the formation of larger short-lived glacial lakes (Narama et al., 2018). Thus, the period of closure is likely determined by the morphology of the ice tunnel and deposition condition of tunnel-closure point (e.g., when melting can open the blocked region). 


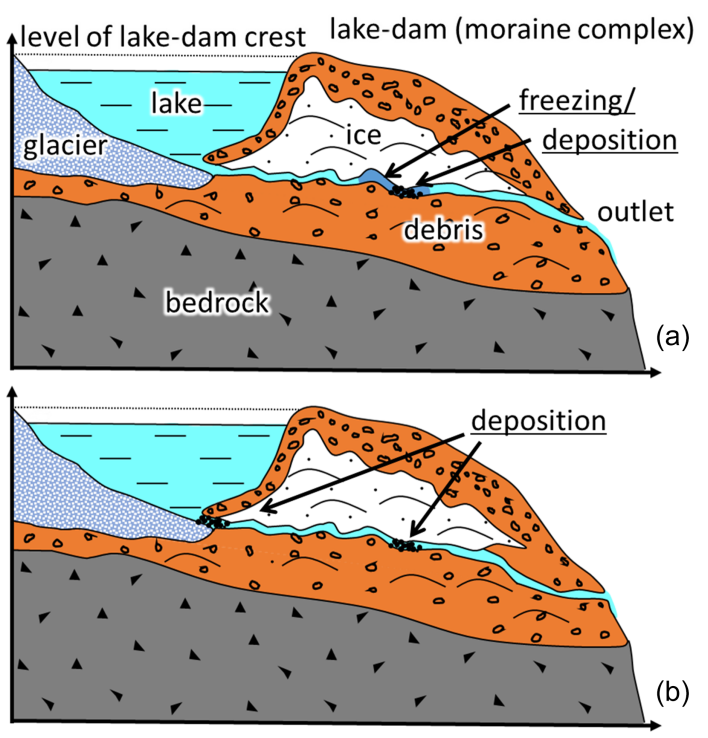

Figure 11. The two types of ice tunnel closure occurring in the northern Teskey Range. Sketches show cross sections through a glacier, lake basin, and ice-cored moraine complex in the case of a short-lived lake (based on Popov, 1987). (a) Deposition-freezing type of closure in the event of an outlet ice tunnel being blocked by freezing of storage water or deposition of debris and ice. Dark blue in the tunnel means frozen. (b) Deposition-collapse type of closure in the event of an outlet ice tunnel being blocked by deposition of debris and ice by thermal erosion (ice melt).

Many of the other short-lived glacial lakes in the northern Teskey Range, observed via satellite imagery, are likely to belong to the deposition-collapse type as well. However, some likely have a larger influence from the water balance between drainage and storage, related to increasing glacial meltwater and tunnel size. Consider Jeruy glacial lake between 2014 and 2016 (Fig. 12). Ice melting caused distinct changes and rapid deposition within the outlet ice tunnel, which likely led to tunnel closure. Thus, morphology and surface characteristics of an ice-cored moraine complex within the mountain permafrost zone are prone to frequent changes, and the deposition-collapse type is likely the main type for the short-lived glacial lakes in the northern Teskey Range. If the deposition-collapse processes occur in summer when the melting rate is high, the formation of a short-lived glacial lake is highly likely.

\subsection{Relationship between outlet tunnel size and lake drainage}

Of the 160 short-lived lakes we identified in 2013-2018, only Jeruy lake in 2013 and Karateke lake in 2014 showed considerable drainage. The estimated maximum discharges from Jeruy $\left(182000 \mathrm{~m}^{3}\right)$ and Karateke $\left(123000 \mathrm{~m}^{3}\right)$ lakes were 14.9 and $11.5 \mathrm{~m}^{3} / \mathrm{s}$, respectively (Narama et al., 2018). These lakes had relatively large outlet tunnels, with one at Jeruy,
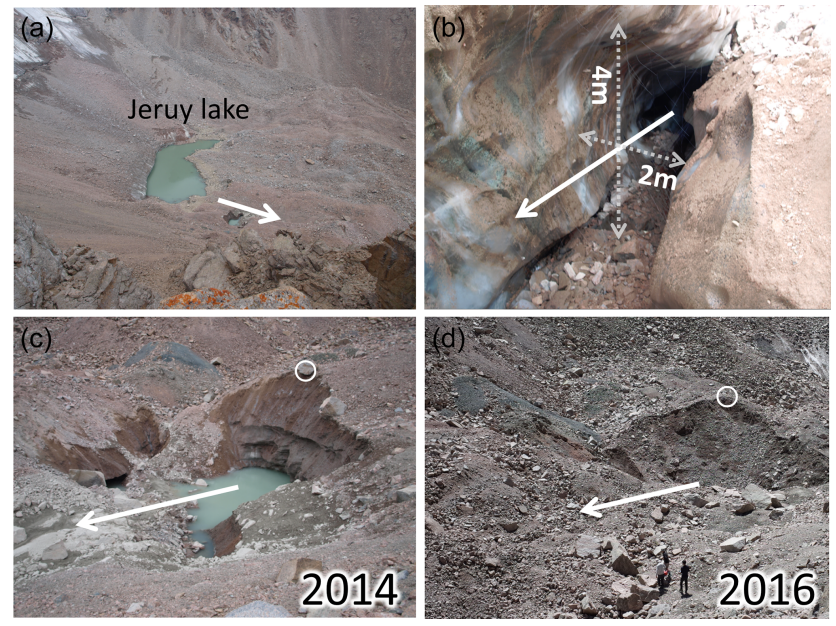

Figure 12. Basin and outlet ice tunnel of Jeruy lake, which drained on 15 August 2013. (a) Lake basin of Jeruy glacial lake on 9 August 2014. The white arrow shows the direction of lake drainage. (b) Insight into the outlet ice tunnel on 9 August 2014. (c) The outlet ice tunnel area on 9 August 2014. The white circles in panels (c) and (d) show the same location. (d) Same as panel (c) except on 9 August 2016.

as well as one at Karateke, having a cross section of about $8 \mathrm{~m}^{2}$ (Fig. 12b). Earlier, in 2008, the western Zyndan lake $\left(437000 \mathrm{~m}^{3}\right)$ emptied at a higher discharge rate of $27 \mathrm{~m}^{3} / \mathrm{s}$ (Narama et al., 2010a). Most of the water in these three cases drained over a period of several hours. In contrast, Korumdu lake did not show such high drainage rates during 2017 2019 , draining at a maximum rate of $0.66 \mathrm{~m}^{3} / \mathrm{s}$ in 2017 , taking $17 \mathrm{~d}$ to drain $234000 \mathrm{~m}^{3}$, and its tunnel cross section was much smaller than those at Jeruy lake or Karateke lake.

In addition, Korumdu lake exhibited sudden fluctuations of water level over several hours, which we argue was related to closure of the small outlet ice tunnel caused by deposition of and blockage by debris. The relatively small tunnel size of this lake resulted in slower lake discharge even when lake volume reached its maximum $\left(330000 \mathrm{~m}^{3}\right)$. During 2017 2019 , the lake size was largest in 2017 , yet discharge rates were in the same order of magnitude every year. These results show that, at least for Korumdu lake, the dimensions of the outlet ice tunnel were the dominant factor controlling lake discharge rates.

However, tunnel dimensions could increase in the future due to thermal erosion and flowing water, allowing greater discharge rates. Meltwater and increasing temperature can accelerate thermokarst processes enlarging the outlet ice tunnel (Sakai et al., 2000; Kääb et al., 2001; Miles et al., 2018). In addition, although lake basin size changes on ice-cored moraine complexes depend on the details of the thermal erosion, the basin area of Korumdu lake has increased each year due to glacier retreat. If these conditions and evolution also apply to other short-lived glacier lakes in the Teskey Range, 
large-scale flooding events during their discharge may become more frequent in the future due to increasing temperature.

\section{Conclusions}

From our field survey (2015-2019), we found that Korumdu lake, located in the Tong region of Teskey Range, northern Tien Shan, appeared and expanded from July to August and then drained over a period of 2-3 weeks. The lake formed when its outlet ice tunnel closed, which we argue was due to deposition of ice-debris mixture during summer. The lake drainage was always relatively slow. We argue that predicting drainage rates requires knowing the dimensions of the outlet ice tunnel and the size of the lake basin. By combining water level data and UAV-derived DSMs from consecutive years, we were able to study the temporal evolution (lake area, volume) and daily lake discharge and approximate the tunnel dimensions to much less than $8 \mathrm{~m}^{2}$. Four lakes that appeared a month earlier (May-June) showed drainage rates significantly higher compared to Korumdu lake. Based on satellite images from 2013-2018, 160 short-lived glacial lakes were detected in the northern Teskey Range, many of which had a timing of appearance similar to Korumdu lake with on average $27 \%$ forming in June and on average $73 \%$ in JulySeptember. This result shows the deposition-collapse type is likely the main type for the short-lived glacial lakes in the northern Teskey Range.

Although short-lived glacial lakes in the northern Teskey Range rarely drain through moraine-dam failure, they can be nevertheless a major flood hazard. Moreover, the warming climate may result in larger outlet ice tunnels and lake basin sizes that could cause large flood events. Therefore, shortlived lakes should be monitored using satellite data and field observations to better understand their characteristics and behavior. Such monitoring may help mitigate glacier-related hazards in permafrost zones of high-mountain areas of Central Asia.

Data availability. Some of the data produced for use in this study can be provided upon request to the corresponding author.

Supplement. The supplement related to this article is available online at: https://doi.org/10.5194/nhess-21-2245-2021-supplement.

Author contributions. MD and CN conducted the field survey and performed an analysis of field and satellite data. MD wrote the paper. $\mathrm{CN}$ improved the manuscript and suggested some discussion points. All authors read and agreed to the published version of the paper.
Competing interests. The authors declare that they have no conflict of interest.

Disclaimer. Publisher's note: Copernicus Publications remains neutral with regard to jurisdictional claims in published maps and institutional affiliations.

Acknowledgements. Special thanks are due to Bolot Moldobekov, Sheishenaly Usupaev, and Azamat Osmonov of the Central-Asian Institute for Applied Geosciences (CAIAG); Anarkul Aitaliev of the Ministry of Emergency Situations of the Kyrgyz Republic; Sergey Erokhin of Institute of Water Problem and Hydropower Engineering of the Kyrgyz Republic Academy of Sciences; and Yoshitaka Mori, Hideyuki Takadama, Naoki Sakurai, Hirotaka Sugiyama, Shun Okuyama, and Naho Yamada of Niigata University for supporting field survey and satellite data analysis. We thank the editor (Margreth Keiler) and two reviewers (Mauro Fischer and anonymous reviewer), who gave us many valuable comments and improvements for rephrasing our paper. This study was supported by Japanese Government (Monbukagakusho: MEXT) Scholarships at the Graduate School of Science and Technology, Niigata University, in 2015-2017; the Sasakawa Scientific Research Grant from the Japan Science Society; Grant-in-Aid for Scientific Research (B) 16H05642 and 19H01372 of the Ministry of Education, Science, Sports and Culture; and the Heiwa Nakajima Research Foundation.

Financial support. This research has been supported by the Ministry of Education, Science, Sports and Culture, Japan (grant nos. 16H05642 and 19H01372).

Review statement. This paper was edited by Margreth Keiler and reviewed by Mauro Fischer and one anonymous referee.

\section{References}

Aizen, V. B., Kuzmichenok, V. A., Surazakov, A. B., and Aizen, E. M.: Glacier changes in the central and northern Tien Shan during the last 140years based on surface and remote-sensing data, Ann. Glaciol., 43, 202-213, 2006.

Ageta, Y., Iwata, S., Yabuki, H., Naito, N., Sakai, A., Narama, C., and Karma: Expansion of glacier lakes in recent decades in the Bhutan Himalayas, Debris-Covered Glaciers, edited by: Nakawo, M., Raymond, C. F., and Fountain, A., IAHS Publication, 264: Wallingford, UK, 165-175, ISBN 978-1-901502-31-2, 2000.

Bajracharya, S. R., Mool, P. K., and Shrestha, B. R.: Impact of Climate Change on Himalayan Glaciers and Glacial Lakes: Case Studies on GLOF and Associated Hazards in Nepal and Bhutan, ICIMOD: Kathmandu, Nepal, 133 pp., ISBN 978-92-9115-0328, 2007.

Benn, D. I., Wiseman, S., and Warren, C. R.: Rapid growth of a supraglacial lake, Ngozumpa Glacier, Khumbu Himal, Nepal, Debris-Covered Glaciers, edited by: Nakawo, M., Raymond, C. 
F., and Fountain, A., IAHS Publication, 264: Wallingford, UK, 177-185, ISBN 978-1-901502-31-2, 2000.

Benn, D. I., Thompson, S., Gulley, J., Mertes, J., Luckman, A., and Nicholson, L.: Structure and evolution of the drainage system of a Himalayan debris-covered glacier, and its relationship with patterns of mass loss, The Cryosphere, 11, 2247-2264, https://doi.org/10.5194/tc-11-2247-2017, 2017.

Bolch, T., Peters, J., Yegorov, A., Pradhan, B., Buchroithner, M., and Blagoveshchensky, V.: Identification of otentially dangerous glacial lakes in the northern Tien Shan, Nat. Hazards, 59, 16911714, 2011.

Costa, J. E. and Schuster, R. L.: The formation and failure of natural dams, Geol. Soc. Am. Bull., 100, 1054-1068, 1988.

Daiyrov, M., Narama, C., Yamanokuchi, T., Tadono, T., Kääb, A., and Ukita, J.: Regional geomorphological conditions related to recent changes of glacial lakes in the Issyk-Kul basin, northern Tien Shan, Geosciences, 8, 99, https://doi.org/10.3390/geosciences8030099, 2018.

Daiyrov, M., Narama, C., Kääb, A., and Tadono, T.: Formation and outburst of Toguz-Bulak glacial lake in the north part of Teskey Range, Tien Shan, Kyrgyzstan, Geosciences, 10, 468, https://doi.org/10.3390/geosciences10110468, 2020.

Dikih, A. N.: Regime of modern glaciation of the Central Tien Shan, Academy of Sciences of Kyrgyz SRR, Ilim, 526, Frunze, 1982.

Emmer, A. and Cochachin, A.: The causes and mechanisms of moraine-dammed lake failures in the Cordillera Blanca, North American Cordillera, and Himalaya. Acta Universitatis Carolinae, Geographica, 48, 5-15, 2013.

Erokhin, S. A., Zaginaev, V. V., Meleshko, A. A., Ruiz-Villanueva, V., Petrakov, D., Chernomorets, S., Viskhadzhieva, K., Tutubalina, O., and Stoffel, M.: Debris flows triggered from nonstationary glacier lake outbursts: the case of the Teztor Lake complex (Northern Tian Shan, Kyrgyzstan), Landslides, 15, 83-98, https://doi.org/10.1007/s10346-017-0862-3, 2017.

Huggel, C.: Assessment of glacial hazards based on remote sensing and GIS modeling, Schriftenreihe Physische Geographie Glaziologie und Geomorphodynamic (Schrift. Phys. Geogr. Glaz. Geomorpho.), 44, 1-75, Zürich, ISBN 385543240 6, 2004.

Iwata, S., Kuroda, S., and Kadar, K.: Debris-mantle formation of Wrpute Glacier, the Tien Shan Mountains, China, Bull. Glaciol. Res., 22, 99-207, 2005.

Janský, B., Šobr, M., Engel, Z., and Yerokhin, S.: High-altitude lake outburst: Tien-Shan case study, in: Evolution of geographical systems and risk processes in the global context, edited by: Dostál, P., chap. 7, Charles University in Prague, Faculty of Science, P3K Publishers, Prague, 113-127, 2008.

Kääb, A. and Haeberli, W.: Evolution of a high-mountain thermokarst lake in the Swiss Alps, Arct. Antarct. Alp. Res., 33, 385-390, https://doi.org/10.1080/15230430.2001.12003445, 2001

Kapitsa, V., Shahgedanova, M., Machguth, H., Severskiy, I., and Medeu, A.: Assessment of evolution and risks of glacier lake outbursts in the Djungarskiy Alatau, Central Asia, using Landsat imagery and glacier bed topography modelling, Nat. Hazards Earth Syst. Sci., 17, 1837-1856, https://doi.org/10.5194/nhess17-1837-2017, 2017.

Komori, J., Gurung, D. R., Iwata, S., and Yabuki, H.: Variation and lake expansion of Chubda Glacier, Bhutan Himalayas, during the last 35 years, Bull. Glaciol. Res., 21, 49-55, 2004.
Kutuzov, S. and Shahgedanova, M.: Glacier retreat and climatic variability in the eastern Teskey-Alatoo, inner Tien Shan between the middle of the 19th century and beginning of the 21st century, Global Planet. Change, 69, 59-70, https://doi.org/10.1016/j.gloplacha.2009.07.001, 2009.

Kuzmichenok, V. A.: Scientific-technical report, Academy of Sciences of the Kyrgyzstan, Bishkek, 61 pp., 2013.

Mergili, M., Kopf, C., Müllebner, B., and Schneider, J. F.: Changes of the cryosphere and related geohazards in the high-mountain areas of Tajikistan and Austria: A comparison, Geogr. Ann. Ser. A Phys. Geogr., 93, 79-96, 2012.

Mergili, M., Müller, J., and Schneider, J. F.: Spatio-temporal development of high-mountain lakes in the headwaters of the Amu Darya River (Central Asia), Glob. Planet. Chang., 107, 13-24, 2013.

Miles, E. S., Willis, I. C., Arnold, N. S., and Steiner, J.: Spatial, seasonal and interannual variability of supraglacial ponds in the Langtang Valley of Nepal, 1999-2013, J. Glaciol., 63, 88-105, https://doi.org/10.1017/jog.2016.120, 2016.

Miles, E. S., Willis, I., Buri, P., Steiner, J. F., Arnold, N. S., and Pellicciotti, F.: Surface pond energy absorption across four Himalayan glaciers accounts for $1 / 8$ of total catchment ice loss, Geophys. Res. Lett., 45, 10464-10473, https://doi.org/10.1029/2018GL079678, 2018.

Nagai, H., Ukita, J., Narama, C., Fujita, K., Sakai, A., Tadono, T., Yamanokuchi, T., and Tomiyama, N.: Evaluating the Scale and Potential of GLOF in the Bhutan Himalayas Using a SatelliteBased Integral Glacier-Glacial Lake Inventory, Geosciences, 7, 77, https://doi.org/10.3390/geosciences7030077, 2017.

Narama, C., Shimamura, Y., Nakayama, D., and Abdrakhmatov, K.: Recent changes of glacier coverage in the western Terskey-Alatoo Range, Kyrgyz Republic, using Corona and Landsat, Ann. Glaciol., 43, 223-229, https://doi.org/10.3189/172756406781812195, 2006.

Narama, C., Duishonakunov, M., Kääb, A., Daiyrov, M., and Abdrakhmatov, K.: The 24 July 2008 outburst flood at the western Zyndan glacier lake and recent regional changes in glacier lakes of the Teskey Ala-Too range, Tien Shan, Kyrgyzstan, Nat. Hazards Earth Syst. Sci., 10, 647-659, https://doi.org/10.5194/nhess10-647-2010, 2010a.

Narama, C., Fujita, K., Duishonakunov, M., Kajiura, T., Daiyrov, M., Usubaliev, R., and Shatravin, V.: Observation of glacier melting in the Chong-Kyzylsuu basin, Kyrgyzstan in 20062009, Project report on an oasis-region, 8(1), 97-104, 2010b (in Japanese).

Narama, C., Daiyrov, M., Kazehare, S., Yamamoto, M., and Tadono T.: Glacier lake inventory of the northern Tien Shan - Kyrgyz, Kungoy, and Teskey Ala-Too Ranges, Report of Mountain Research Group of Niigata University, Niigata, Japan, Niigata Printing, 2015.

Narama, C., Daiyrov, M., Tadono, T., Yamamoto, M., Kääb, A., Morita, R., and Ukita, J.: Seasonal drainage of supraglacial lakes on debris-covered glaciers in the Tien Shan Mountains, Central Asia, Geomorphology, 286, 133-142, https://doi.org/10.1016/j.geomorph.2017.03.002, 2017.

Narama, C., Daiyrov, M., Duishonakunov, M., Tadono, T., Sato, H., Kääb, A., Ukita, J., and Abdrakhmatov, K.: Large drainages from short-lived glacial lakes in the Teskey Range, Tien Shan Moun- 
tains, Central Asia, Nat. Hazards Earth Syst. Sci., 18, 983-995, https://doi.org/10.5194/nhess-18-983-2018, 2018.

Neupane, R., Chen, H., and Cao, C.: Review of moraine dam failure mechanism. Geomatics, Nat. Hazards Risk, 10, 1948-1966, https://doi.org/10.1080/19475705.2019.1652210, 2019.

Podrezov, O. A. and Ryskal', M. O.: Validation of precipitation data of multi satellite tmpa model for the Kyrgyzstan mountainous TERRITORY, Geogr. Bull., 1, 63-74, https://doi.org/10.17072/2079-7877-2019-1-63-74, 2019.

Popov, N. V.: Outburst glacial mudflows and their prevention in the mountains of Northern Tien Shan, Data Glaciol. Stud., 59, 188193, 1987 (in Russian).

Richardson, S. D. and Reynolds, J. M.: An overview of glacial hazards in the Himalayas, Quatern. Int., 65-66, 31-47, 2000.

Sakai, A., Takeuchi, N., Fujita, K., and Nakawo, M.: Role of supraglacial ponds in the ablation process of a debris-covered glacier in the Nepal Himalayas, Debris-Covered Glaciers, edited by: Nakawo, M., Raymond, C. F., and Fountain, A., IAHS Publication: Wallingford, UK, 264, 119-132, ISBN 978-1-90150231-2, 2000.
Shatravin, V. I.: Reconstruction of glaciation in the Pleistocene and Holocene based on new method, in: Climate, Glaciers, Lakes of Tien-Shan: travel in the past, edited by: Romanovsky, V. V., The Institute of Water Problems and Hydropower, Bishkek, 26-46, 2007 (in Russian).

Shreshta, B. B.: Glacial Lake Outburst due to Moraine Dam Failure by Seepage and Overtopping with Impact of Climate Change, Annuals of Disas. Prev. Res., 53B, Inst., Kyoto Univ., 2010.

Wang, X., Ding, Y., Liu, S., Jiang, L., Wu, K., Jiang, Z., and Guo, W.: Changes of glacial lakes and implications in Tian Shan, Central Asia, based on remote sensing data from 1990 to 2010, Environ. Res. Lett., 8, 1-11, https://doi.org/10.1088/17489326/8/4/044052, 2013.

Watson, C. S., Quincey, D., Carrivick, J., and Smith, M.: The dynamics of supraglacial ponds in the Everest region, central Himalaya, Glob. Planet. Change, 142, 14-27, https://doi.org/10.1016/j.gloplacha.2016.04.008, 2016. 